\title{
Theoretical analysis on Asset-Liability Management of liquidity risk: the case of Islamic banks
}

\author{
Fatima AIT MALHOU ${ }^{1 *}$, Ahmed MAIMOUN ${ }^{2}$ \\ ${ }^{1}$ Research Laboratory in economics, management and business management, Hassan First University \\ of Settat, Morocco \\ ${ }^{2}$ Research Laboratory in economics, management and business management, Hassan First University \\ of Settat, Morocco
}

\begin{abstract}
The main objective of this research is to identify and review all the studies conducted to investigate the relationship between liquidity risk and Asset-Liability Management in Islamic banks. This systematic review was conducted using the Preferred Reporting Items for Systematic Reviews and Meta-Analyses guidelines (PRISMA Statement ${ }^{\circledR}$ ). During the past two decades, a limited amount of literature has been published on Asset-Liability Management in Islamic banks. In fact, from the 1886 articles collected, only 25 studies were included, 8 of them are considered the most relevant ones. It is important to note that most of the selected articles pointed out the importance of practical asset-liability management approaches and techniques used to mitigate liquidity risk. This study gives an overview of the Asset-liability management in Islamic banks considered as an under-researched topic. It identifies the problems, the challenges and the practical approaches adopted by bankers in managing liquidity risk through assets and liabilities. It therefore shows the need for more empirical studies to ensure better conditions and framework for the Islamic financial industry. This is the first review to investigate the previous studies on the Asset-Liability Management of liquidity risk in Islamic banks. The main limitation could be related to some potential relevant works that have not been included in this study. This is due the limited number of databases that the authors had access to.
\end{abstract}

\section{Introduction}

After the international financial crisis, banks can no longer ignore the importance of a robust liquidity risk management. This topic has been increasingly recognised as a serious worldwide concern. The dramatic effects of the recent international financial crisis on the stability of financial systems can be explained mainly by the poor management of the banks' assets and liabilities [1]. For this reason, Asset-Liability management has recently been given more attention to reducing financial risks.

* Corresponding author: f.aitmalhou@uhp.ac.ma 
According to a definition provided by Greuning and Iqbal [2], Asset-liability management consists of practices and approaches used by banks to determine and control all the aspects related to the assets and liabilities (volume, structure, maturity... etc). It aims to provide the optimal structure of assets and liabilities and therefore ensure high-quality, stable, and growing flows and income. This practice has emerged in the United States in the 1980s. Today, it is deemed to be an essential component of efficient risk management.

Liquidity risk is bank's ability to cover the need for liquidity available. It consists of balancing the demand for liquidity on the liability side with the supply of liquidity on the asset side.

Liquidity risk results from not being able to balance between these two sides and not having external sources to obtain funds.

Asset-liability management risk arises from the difference in maturity terms and conditions on a bank's assets and liabilities. Like conventional banks, Islamic banks are also exposed to asset-liability mismatch risk. However, this risk is theoretically supposed to be less present in Islamic banks as they act as agents for investors-depositors and pass all profits and losses through to them [2]. This contradicts many studies that found that this risk is even more present in Islamic banks as they operate in an extremely challenging environment mainly due to the absence of Shariah-compliant money markets and interbank markets.

This study aims to systematically review the studies which have been conducted investigating the relationship between Asset-Liability Management and liquidity risk in Islamic banks. More particularly, it aims to determine the themes reporting on the assetliability management of liquidity risk in Islamic banks. It tries to answer these questions by exploring and analysing the most relevant previous works that has been published on this area.

This article seeks to address the following questions: How does liquidity risk arises in Islamic banks? How do asset and liability sides contribute to the emergence of liquidity risk in Islamic banks?

This paper makes an original contribution to Islamic finance literature. This is the first work to undertake a review of the existing studies on ALM in Islamic banks. It is interesting to note that in the previous works on ALM, the studies covering this topic in Islamic banks are too limited [3]. Therefore, This work enhances the understanding of this under-researched topic.

In this systematic literature review, after presenting a general background on ALM in Islamic banks. Section 2 explains the Preferred Reporting Items for Systematic reviews and Meta-Analyses (PRISMA), a method used to screen and select the articles. Section 3 presents the articles deemed to be the most relevant ones to be analysed. Section 4 provides an analysis of the results. Finally, the last section concludes.

\section{Methodology}

Systematic reviews have become increasingly important in finance, allowing regular updates of information on this field. Characterised by its methodological rigour, a systematic review is based on systematic approaches and a detailed search strategy in order to identify all relevant studies on a particular area. In this paper, a Systematic review was conducted using the Preferred Reporting Items for Systematic reviews and Meta-Analyses (PRISMA) method.

The PRISMA is a method developed by experts in methodology to conduct systematic reviews. It systematically identifies, screens and selects the most relevant studies in a 
particular area through four phases namely identification, screening, eligibility and inclusion.

To define and delimit this specific area of the research, it is important that the keywords linked to the paper's topic are well identified. The main keywords selected are: "AssetLiability Management", "Liquidity", and "Islamic banks". To enhance the probability of obtaining relevant results, the table below presents the most suitable keywords and their synonyms for use in this study.

Table 1. Various combinations of the selected keywords and their synonyms used in the study

\begin{tabular}{|c|c|c|c|c|c|}
\hline $\begin{array}{l}\text { Lett } \\
\text { er }\end{array}$ & $\begin{array}{l}\text { Keyword } \\
\text { S }\end{array}$ & $\begin{array}{l}\text { Synony } \\
\mathrm{m} 1\end{array}$ & $\begin{array}{r}\text { Syn } \\
\text { onym } 2 \\
\end{array}$ & $\begin{array}{l}\text { Expre } \\
\text { ssion }\end{array}$ & $\begin{array}{l}\text { Combi } \\
\text { nation }\end{array}$ \\
\hline $\mathrm{A}$ & $\begin{array}{c}\text { Asset } \\
\text { Liability } \\
\text { Management }\end{array}$ & $\begin{array}{c}\text { balance } \\
\text { sheet } \\
\text { management }\end{array}$ & $\begin{array}{l}\mathrm{AL} \\
\mathrm{M}\end{array}$ & $\begin{array}{l}\text { A-A1- } \\
\text { A2 }\end{array}$ & $\begin{array}{l}\mathrm{A}+\mathrm{B}+ \\
\mathrm{C}\end{array}$ \\
\hline B & Liquidity & cash & - & $\begin{array}{l}\text { B-B1- } \\
\text { B2 }\end{array}$ & $\begin{array}{l}\mathrm{B}+\mathrm{A}+ \\
\mathrm{C} \\
\end{array}$ \\
\hline $\mathrm{C}$ & $\begin{array}{l}\text { mitigatio } \\
\mathrm{n}\end{array}$ & $\begin{array}{l}\text { reductio } \\
\mathrm{n}\end{array}$ & $\begin{array}{r}\text { mini } \\
\text { misation }\end{array}$ & $\begin{array}{l}\text { C-C1- } \\
\mathrm{C} 2 \\
\end{array}$ & $\mathrm{C}+\mathrm{B}+\mathrm{E}$ \\
\hline D & Bank & $\begin{array}{l}\text { financial } \\
\text { institution }\end{array}$ & - & $\begin{array}{l}\text { D-D1- } \\
\text { D2 }\end{array}$ & $\begin{array}{l}\mathrm{D}+\mathrm{B}+ \\
\mathrm{A}\end{array}$ \\
\hline $\mathrm{E}$ & $\begin{array}{l}\text { Islamic } \\
\text { bank }\end{array}$ & $\begin{array}{l}\text { Islamic } \\
\text { finance }\end{array}$ & $\begin{array}{c}\text { Isla } \\
\text { mic } \\
\text { Financia } \\
1 \\
\text { instituti } \\
\text { ons } \\
\end{array}$ & $\begin{array}{l}\text { E-E1- } \\
\text { E2 }\end{array}$ & $E+A+B$ \\
\hline- & - & - & - & - & $\ldots$ \\
\hline
\end{tabular}

The study was made based on online journals and databases. Most of the papers which have been deemed pertinent were obtained from the sources listed below:

- SpringerLink

- Web of Science

- Scopus

- ScienceDirect

- Jstor

The initial sample consisted of papers from 2000 to 2019 . In order to identify the most relevant ones, the main criterion for selecting articles is their relation with the following subjects:

- Asset-Liability Management in Islamic banks

- Asset-Liability Management and liquidity risk

- Liquidity risk mitigation in Islamic banks

It should be noted that the final articles included in the study are analysed using NVivo software. By employing models to explore the covered subjects and visualize them, data can be viewed at various levels.

\section{Results}

It can be seen from the data in Table 2 and figure 1 that from a total of 1886 papers, only 25 were included in the study for their relevance. The rest of the articles were deemed 
irrelevant to the current work and were eliminated based on exclusion criteria. Criteria for selecting the articles included / excluded from the study were as follows:

Inclusion criteria

- Islamic banks population; and

- Papers that investigated ALM in relation to liquidity risk.

Exclusion criteria

- Duplicate articles

- Articles published before 2000;

- Articles published in other languages than English and French;

- Off-topic articles

- Documents other than journal and review articles

The following figure (Figure1.) shows the searching stages and the results obtained in each stage. These stages are summarized in four phases, namely identification of the articles, screening them through introducing exclusion criteria, eligibility and inclusion of the final articles deemed relevant to the study. From the identification stage, 1886 was the number of articles identified after entering the chosen keywords into the databases. The second phase was screening. In this step, a number of filters were applied according to some exclusion criteria. In this paper, 26 duplicate records were first removed. The 1860 remaining articles were then filtered according to the criteria previously established, namely the date (11 papers were excluded because they were published before 2000, 1086 documents removed for their type, 22 articles excluded as they were published in languages other than English and French, and finally, 430 papers were excluded as they were off-topic). In total, the screened papers represent 1575 from 1886 initially identified. The third phase was eligibility, which can also be called "inclusion screening". At this stage, papers considered relevant to the review are included. Practically, the irrelevant papers are excluded after a first reading of the titles and the abstracts, then the screeners read and examine the full-text versions of the articles remaining to decide whether or not these articles will be included. In this paper, after having screened 1575 in the two previous stages, 311 full-text articles were examined for eligibility and 286 were excluded by irrelevance. Consequently, 25 final articles were included in the systematic review.

Table 2. The results obtained from the process of eliminating non-relevant articles 


\begin{tabular}{|c|c|c|c|c|c|c|c|}
\hline \multirow[t]{2}{*}{$\begin{array}{l}\text { Databas } \\
\text { es }\end{array}$} & \multirow{2}{*}{$\begin{array}{r}\text { A } \\
\text { rticles } \\
\mathrm{C} \\
\text { ollect } \\
\text { ed }\end{array}$} & \multicolumn{5}{|c|}{$\begin{array}{l}\text { Number of articles excluded after the introduction of the } \\
\text { criteria : }\end{array}$} & \multirow[t]{2}{*}{$\begin{array}{l}\text { Selected } \\
\text { Articles }\end{array}$} \\
\hline & & $\begin{array}{l}\text { Repeate } \\
\quad \mathrm{d}\end{array}$ & $\begin{array}{c}\text { Dat } \\
\mathrm{e}: \\
>=2000\end{array}$ & $\begin{array}{l}\text { Type of } \\
\text { Article: } \\
\text { Journal } \\
\text { Articles, } \\
\text { Review }\end{array}$ & $\begin{array}{l}\quad \text { Lang } \\
\text { uage: } \\
\text { English } \\
\& \text { Frenc } \\
\text { h }\end{array}$ & $\begin{array}{l}\text { Off }^{\text {Off }} \\
\text { pic }\end{array}$ & \\
\hline $\begin{array}{l}\text { Springer } \\
\text { Link }\end{array}$ & 318 & 9 & 0 & 957 & 10 & 286 & 56 \\
\hline $\begin{array}{l}\text { Web of } \\
\text { Science }\end{array}$ & $37^{3}$ & 10 & 9 & 56 & 6 & 92 & 164 \\
\hline Scopus & $\begin{array}{ll}1 \\
37 \\
\end{array}$ & 1 & 0 & 45 & 6 & 17 & 68 \\
\hline $\begin{array}{l}\text { Science } \\
\text { Direct }\end{array}$ & $2^{7}$ & 6 & 2 & 23 & 0 & 22 & 19 \\
\hline Jstor & $2^{2}$ & 0 & 0 & 5 & 0 & 13 & 4 \\
\hline Total & $\begin{array}{r}1 \\
886 \\
\end{array}$ & 26 & 11 & 1086 & 22 & 430 & 311 \\
\hline
\end{tabular}

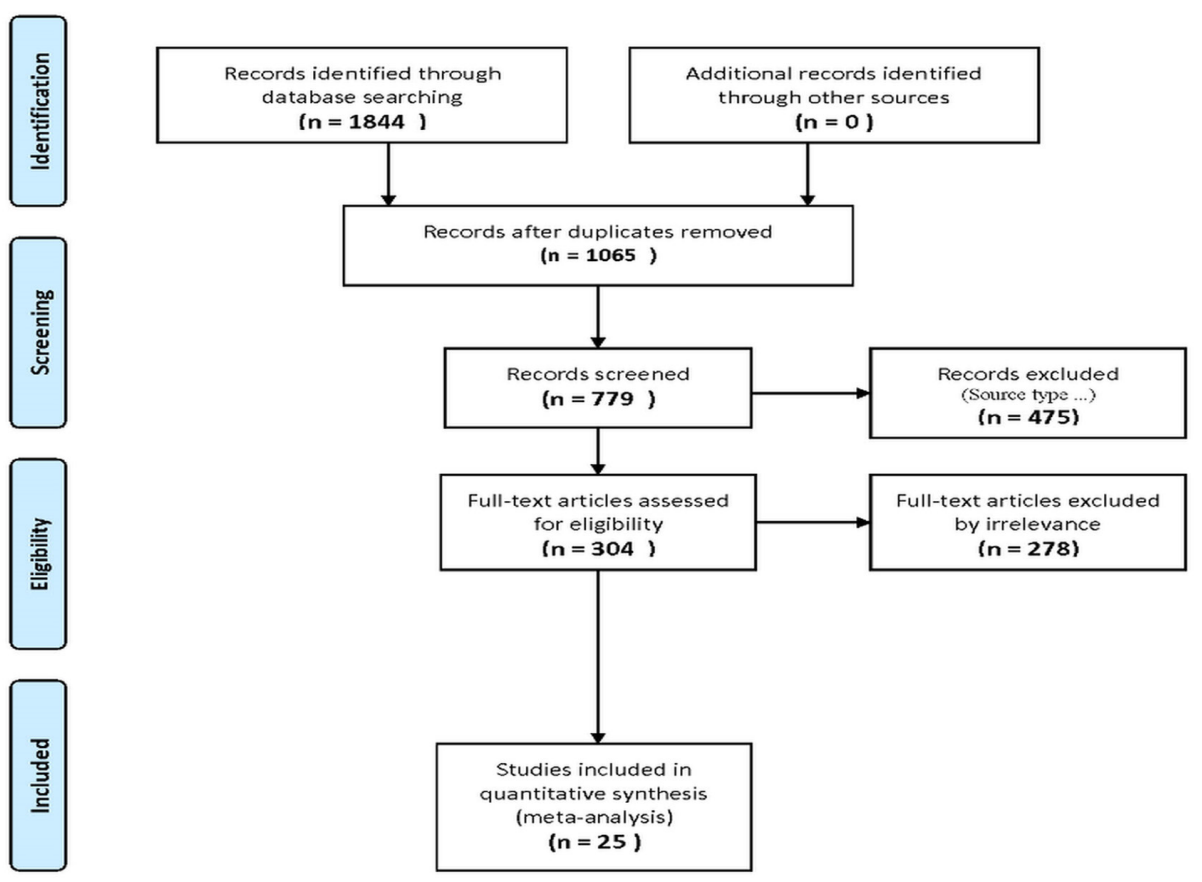

Figure 1. Flow diagram showing the stages of the systematic literature review [4] 


\section{Discussion of results}

After assessing the content of the 25 articles, it has been found that they are all related to some extent to the research problem.

\section{Liquidity Risk in Islamic banks}

First, concerning liquidity risk in Islamic banks, this subject is covered by the selected articles under four aspects that can be visualized in table 3 .

In analyzing the articles discussing liquidity risk issue in Islamic banks. It can be seen that each article covers several aspects. As shown in the above table, the identified articles deal with this issues under four different angles, namely the factors impacting liquidity risk, the state of liquidity risk, liquidity risk management and the recommendations to minimise liquidity risk.

Table 3. Global view of liquidity risk in Islamic banks

\begin{tabular}{|c|c|c|}
\hline Aspects covered & Issues discussed & Articles \\
\hline \begin{tabular}{lr}
\multicolumn{1}{l}{ The } & factors \\
impacting & liquidity \\
risk &
\end{tabular} & $\begin{array}{l}-\quad \text { Identifying liquidity } \\
\text { risk sources } \\
-\quad \text { The determinants of } \\
\text { liquidity risk }\end{array}$ & $\begin{array}{l}\text { - (Abdel Megeid, 2017) [4] } \\
\text { - (Abdul-Rahman et al., 2017) [5] } \\
\text { - (Alzoubi, 2017) [6] }\end{array}$ \\
\hline $\begin{array}{l}\text { The state of } \\
\text { liquidity risk }\end{array}$ & $\begin{array}{l}\text { - Assessing the level of } \\
\text { liquidity risk in Islamic banks } \\
-\quad \text { Comparing liquidity } \\
\text { risk in Islamic and traditional } \\
\text { banks }\end{array}$ & $\begin{array}{l}\text { - (Abu Hussain and AI-Ajmi, 2012) } \\
\text { [7] } \\
\text { - (Ben Selma Mokni et al., 2014) [8] } \\
\text { - (Ahmed, 2015) [9] } \\
\text { - (Safiullah and Shamsuddin, 2017) } \\
\text { [10] } \\
\text { - (Waeibrorheem Waemustafa and } \\
\text { Suriani Sukri, 2016) [11] } \\
\text { - (Hafez, 2015) [12] } \\
\text { - (Ismal, 2010a) [13] }\end{array}$ \\
\hline $\begin{array}{l}\text { Liquidity } \\
\text { management }\end{array}$ & $\begin{array}{l}\text { - The instruments and } \\
\text { practices of liquidity risk } \\
\text { management } \\
\text { - Liquidity management } \\
\text { policies }\end{array}$ & $\begin{array}{l}\text { - (Ben Salah Mahdi and Boujelbene } \\
\text { Abbes, 2017) [14] } \\
\text { - (Abdel Megeid, 2017) [15] } \\
\text { - (Ben Selma Mokni et al., 2014) [8] } \\
\text { - (Ahmed, 2015) [9] } \\
\text { - (Rosman and Abdul Rahman, 2015) } \\
\text { [16] } \\
\text { - (Shafique et al., 2013) [17] } \\
\text { - [17](Rashid and Ramachandran, } \\
\text { 2017) [18] } \\
\text { - (Rehman et al., 2017) [19] } \\
\text { - (Ariffin et al., 2009) [20] }\end{array}$ \\
\hline $\begin{array}{l}\text { Solutions and } \\
\text { recommendations }\end{array}$ & \begin{tabular}{l}
\multicolumn{2}{c}{ Recommendations and } \\
proposals to minimize \\
liquidity risk
\end{tabular} & $\begin{array}{l}\text { - (Rashid and Ramachandran, 2017) } \\
\text { [18] } \\
\text { - (Ismal, 2010a) [13] }\end{array}$ \\
\hline
\end{tabular}


As regards the state of liquidity risk in Islamic banks, there is a general agreement that the liquidity risk is one of the most significant risks facing these banks [7] [8] [10] [11] [12]. These studies have drawn the same conclusions despite the differences in terms of location, sample and methodology.

Numerous studies have attempted to explain the presence of liquidity risk in Islamic banks, Abdel Megeid [15] evaluated the effectiveness of the liquidity risk in Islamic banks, his study concluded that loan quality and liability management positively impact bank's liquidity, while the asset quality has a negative effect on liquidity.

Abdul-Rahman, Said, and Sulaiman [4] have examined the relationship of liquidity risk and the financing structure, and the results showed that the liquidity risk is enhanced by the real estate financing and the short-term financing structure.

Other factors may also impact liquidity risk in Islamic banks namely the bank size and equity. According to Alzoubi [6], a negative correlation was found between liquidity risk and the bank's size, it is generally less present in large banks than in small ones, the reason for this is that clients get more stability and safety with major banks compared to the smaller ones. According to the same source, Bank's equity also impacts liquidity risk. Banks having a higher ratio of equity generally have a lower liquidity risk level, since equity represents a stable source of funding.

Table 4. A global view of asset-liability management in Islamic banks

\begin{tabular}{|ll|ll|}
\hline & State, structure, issues... & & Recommendations and proposals \\
\hline- & (Berger et al., 2019) [21] & - & (Chattha and Alhabshi, 2018) [22] \\
- & (Chattha and Alhabshi, 2018) [22] & - & (Ling et al., 2016) [29] \\
- & (Abou-El-Sood and El-Ansary, 2017) & - & (Ismal, 2010b) [30] \\
& $\quad$ 223] & - & (Ali, 2007) [28] \\
- & (bello et al., 2017) [24] & & \\
- & (Majid et al., 2014) [25] & \\
- & (Sun et al., 2014) [26] \\
- & (Bidabad and Allahyarifard, 2008) [27] \\
- & (Ali, 2007) [28]
\end{tabular}

Concerning liquidity risk management in Islamic banks, numerous studies have reported analyses that identified, evaluated and compared the practices and the methods used in managing liquidity risk. These studies were conducted in different countries using different methodologies. Almost all the findings agree on the lack of instruments to manage this risk [14] [8] [9] [16]. It has also been shown in other studies conducted in Islamic banks that the management of liquidity risk in those banks is generally for low-level [16] [19] and is underperforming compared to conventional banks [15] [17]. 
In analyzing the literature review related to the Asset-liability management (ALM) of Islamic banks, it was revealed that it is severely restricted. From a first examination of the contents of the articles deemed relevant using the methodology mentioned above, these articles could be divided into two categories: the articles that examine, analyze and compare the structure and the instruments of ALM, and the articles presenting recommendations and proposals for better management of the assets and liabilities.

The first finding obtained reading the content of the selected articles is that the vast majority of the articles closely link assets-liability management to liquidity risk. Several papers opted for the evaluation of Islamic banks assets and liabilities. Based upon previous works comparing Islamic banks with traditional ones, Two studies [22] [31] revealed that both of these banks suffer from serious mismatches between assets and liabilities. The study of Chattha and Alhabshi [22] confirmed that Islamic banks have more duration gap variations compared to conventional banks, which exposes Islamic banks to severe liquidity problems.

Other studies, for their part, focused on the assessment of the two sides of the bank's balance sheet. Majid, Musnadi and Putra [25] have compared asset management in Islamic and traditional banks and concluded that the asset management in Islamic banks is of a higher quality than in conventional ones. This interpretation contradicts the study of Sun and al. [26], who claimed that the assets and liabilities' quality is better in traditional banks than their Islamic counterparts. Islamic banks use short-term borrowings and deposits to invest in longer-term loans and assets, which contradicts the Islamic finance theoretical model, which assumes that Islamic finance offers a "pass-through" of risk to investors and depositors and therefore exposes the banks to less risk. A study [28] also tested this aspect and demonstrated that Islamic bank's assets are intended for the financing of fixed-income assets, particularly murabahah contract and its variants. In the same vein, Berger et al [21] revealed that Islamic banks hold fewer securities and distribute more loans than banks.

Concerning the assets-liability practices in Islamic banks, some ALM approaches dissimilarities were observed between Islamic and conventional banks, this might be related to the particularity of the nature and activities conducted by Islamic banks [27] . However, Ariffin, Archer and Karim [20] revealed that the techniques adopted to measure risks in Islamic banks are less advanced, this is exemplified by the widespread use of maturity and gap analysis approaches by most Islamic banks.

Finally, several works offered detailed recommendations to improve ALM practices in Islamic banks. Many studies have emphasised the critical role of the ALM Committee in the development of new instruments and innovative solutions to manage risks, including profit-and-loss sharing contracts that minimize the asset-liability gap [22] [19]. On the other hand, it was suggested that the liquidity management on both sides of the balance sheet be restructured according to a complete and integrated programme that allows better use of liquid instruments [13] .

Ling and al [29], as for them, developed an

efficient balance sheet, using optimization approach to the multiple objectives by adding penalty cost functions to cover five main goals in ALM. While Ali [28] recommended, instead, that Islamic banks keep a well-estimated portion of assets in liquid form to cater to liquidity withdrawals, based on the behavioral maturity of deposits instead of their contractual maturity. 


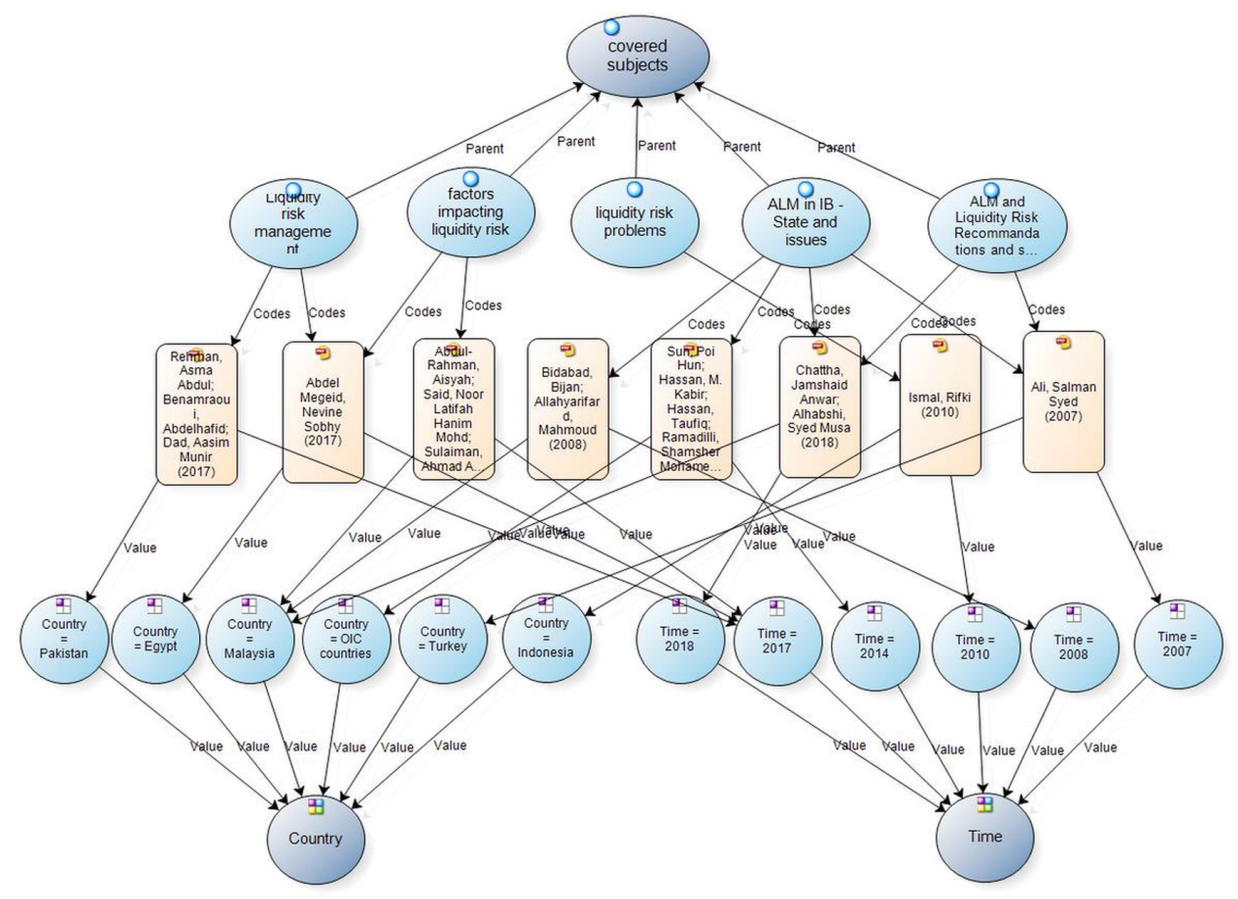

Figure 2. Visualization of key themes and contents of the systematic literature review

\section{Conclusion}

The paper has tried to identify, review and analyse the studies conducted on asset-liability management of liquidity risk in Islamic banks. Using the Preferred Reporting Items for Systematic Reviews and Meta-Analyses guidelines, 25 articles from a total of 1886 were considered as relevant to the research. Eight of them are directly related to the topic. From the results, the first finding is related to the limited literature on asset-liability management in Islamic banks. The studies conducted also show that unlike to what had been assumed by the theoretical model, Islamic banks are also exposed to asset-liability mismatch risk. Their situation is even more complicated as they operate in an extremely challenging environment in terms of liquidity resulting from the scarcity of Shariah-compliant instruments to provide liquidity when needed and at a reasonable cost. Based on the lack observed in literature in this area, the authors found it appropriate to deal with this subject in detail to investigate further the importance of asset-liability management in Islamic banks and its impact on liquidity risk. 


\section{References}

[1] K. Prasad et K. R. Suprabha, «Anomalies in Maturity GAP: Evidence from Scheduled Commercial Banks in India », Procedia Economics and Finance, vol. 11, p. 423-430, 2014, doi: 10.1016/S2212-5671(14)00209-3.

[2] H. van Greuning et Z. Iqbal, Risk analysis for Islamic banks. Washington, D.C: World Bank, 2008.

[3] H. Abou-El-Sood et O. El-Ansary, « Asset-liability management in Islamic banks: evidence from emerging markets ", Pacific Accounting Review, vol. 29, no 1, p. 55-78, févr. 2017, doi: 10.1108/PAR-04-2016-0050.

[4] D. Moher, A. Liberati, J. Tetzlaff, D. Altman, et the PRISMA Group, « Preferred Reporting Items for Systematic Reviews and Meta-Analyses: The PRISMA Statement. » 2009.

[5] A. Abdul-Rahman, N. L. H. M. Said, et A. A. Sulaiman, « Financing Structure and Liquidity Risk: Lesson from Malaysian Experience », Journal of Central Banking Theory and Practice, vol. 6, no 2, p. 125-148, mai 2017, doi: 10.1515/jcbtp-2017-0016.

[6] T. Alzoubi, "Determinants of liquidity risk in Islamic banks », Banks and Bank Systems, vol. 12, no 3, p. 142-148, sept. 2017, doi: 10.21511/bbs.12(3).2017.10.

[7] H. Abu Hussain et J. Al-Ajmi, «Risk management practices of conventional and Islamic banks in Bahrain », The Journal of Risk Finance, vol. 13, no 3, p. 215-239, mai 2012, doi: 10.1108/15265941211229244.

[8] R. Ben Selma Mokni, A. Echchabi, D. Azouzi, et H. Rachdi, « Risk management tools practiced in Islamic banks: evidence in MENA region », Journal of Islamic Accounting and Business Research, vol. 5, no 1, p. 77-97, avr. 2014, doi: 10.1108/JIABR10-2012-0070.

[9] H. Ahmed, «Basel III liquidity requirement ratios and Islamic banking », J Bank Regul, vol. 16, no 4, p. 251-264, nov. 2015, doi: 10.1057/jbr.2014.20.

[10] M. Safiullah et A. Shamsuddin, «Risk in Islamic banking and corporate governance », Pacific-Basin Finance Journal, vol. 47, p. 129-149, 2017, doi: 10.1016/j.pacfin.2017.12.008.

[11] Waeibrorheem Waemustafa et Suriani Sukri, «Systematic and Unsystematic Risk Determinants of Liquidity Risk Between Islamic and Conventional Banks », International Journal of Economics and Financial Issues, 2016, doi: 10.6084/m9.figshare.4052316.

[12] H. M. Hafez, «Risk management practices in Egypt: a comparison study between islamic and conventional banks », Risk Governance and Control: Financial Markets \& Institutions, vol. 5, no 4, 2015, doi: 10.22495/rgcv5i4c2art1.

[13] R. Ismal, "Assessment of liquidity management in Islamic banking industry », International Journal of Islamic and Middle Eastern Finance and Management, vol. 3, no 2, p. 147-167, juin 2010, doi: 10.1108/17538391011054381.

[14] I. Ben Salah Mahdi et M. Boujelbene Abbes, « Relationship between capital, risk and liquidity: a comparative study between Islamic and conventional banks in MENA region », Research in International Business and Finance, vol. 45, p. 588-596, 2017, doi: 10.1016/j.ribaf.2017.07.113.

[15] N. S. Abdel Megeid, "Liquidity risk management: conventional versus Islamic banking system in Egypt », Journal of Islamic Accounting and Business Research, vol. 8, no 1, p. 100-128, févr. 2017.

[16] R. Rosman et A. R. Abdul Rahman, « The practice of IFSB guiding principles of risk management by Islamic banks: International evidence », Journal of Islamic Accounting and Business Research, vol. 6, no 2, p. 150-172, sept. 2015, doi: 10.1108/JIABR-09-2012-0058. [17] O. Shafique, N. Hussain, et M. Taimoor Hassan, «Differences in the risk management practices of Islamic versus conventional financial institutions in Pakistan: An 
empirical study », The Journal of Risk Finance, vol. 14, no 2, p. 179-196, févr. 2013, doi: 10.1108/15265941311301206.

[18] M. Rashid et J. Ramachandran, «Cross-country panel data evidence of the determinants of liquidity risk in islamic banks: a contingency theory approach », International Journal of Business and Society, vol. 18, p. 3-22, 2017.

[19] A. A. Rehman, A. Benamraoui, et A. M. Dad, « A comparative study of Islamic and conventional banks' risk management practices: empirical evidence from Pakistan », Journal of Banking Regulation, vol. 19, no 3, p. 222-235, 2017, doi: 10.1057/s41261-0170046-z.

[20] N. M. Ariffin, S. Archer, et R. A. A. Karim, « Risks in Islamic banks: Evidence from empirical research », Journal of Banking Regulation, vol. 10, no 2, p. 153-163, mars 2009, doi: $10.1057 /$ jbr.2008.27.

[21] A. N. Berger, N. Boubakri, O. Guedhami, et X. Li, « Liquidity Creation Performance and Financial Stability Consequences of Islamic Banking: Evidence from a Multinational Study », Journal of Financial Stability, p. 100692, juill. 2019, doi: 10.1016/j.jfs.2019.100692.

[22] J. A. Chattha et S. M. Alhabshi, « Benchmark rate risk, duration gap and stress testing in dual banking systems », Pacific-Basin Finance Journal, sept. 2018, doi: 10.1016/j.pacfin.2018.08.017.

[23] H. Abou-El-Sood et O. El-Ansary, « Asset-liability management in Islamic banks: evidence from emerging markets », Pacific Accounting Review, vol. 29, no 1, p. 55-78, févr. 2017, doi: 10.1108/PAR-04-2016-0050.

[24] nabil bello, hasan Aznan, et B. Saiti, « The mitigation of liquidity risk in Islamic banking operations », Banks and Bank Systems, vol. 12, no 3, p. 154-165, oct. 2017, doi: 10.21511/bbs.12(3-1).2017.01.

[25] M. S. A. Majid, S. Musnadi, et I. Y. Putra, « A Comparative Analysis of the Quality of Islamic and Conventional Banks' Asset Management in Indonesia », Gadjah Mada International Journal of Business, vol. 16, no 2, p. 17, 2014.

[26] P. H. Sun, M. K. Hassan, T. Hassan, et S. M. Ramadilli, « The assets and liabilities gap management of conventional and Islamic banks in the organization of Islamic cooperation (OIC) countries », Applied Financial Economics, vol. 24, no 5, p. 333-346, mars 2014, doi: 10.1080/09603107.2013.877568.

[27] B. Bidabad et M. Allahyarifard, «Assets and Liabilities Management in Islamic Banking », The 3rd International Conference on Islamic banking and Finance, Karachi, Pakistan., p. 18, 2008.

[28] S. S. Ali, "FINANCIAL DISTRESS AND BANK FAILURE: LESSONS FROM CLOSURE OF IHLAS FINANS IN TURKEY », Islamic Economic Studies, vol. 14, no 1, p. $52,2007$.

[29] C. H. Ling, R. binti Muhamad, Ab. M. Bin Ab. Ghani, et R. Ramasamy, « An Islamic bank multi-objective balance sheet management model », International Journal of Applied Business and Economic Research, vol. 14, no 2, p. 885-913, 2016.

[30] R. Ismal, «Strengthening and improving the liquidity management in Islamic banking », Humanomics, vol. 26, no 1, p. 18-35, févr. 2010, doi: 10.1108/08288661011024977.

[31] P. H. Sun, M. K. Hassan, T. Hassan, et S. M. Ramadilli, « The assets and liabilities gap management of conventional and Islamic banks in the organization of Islamic cooperation (OIC) countries », Applied Financial Economics, vol. 24, no 5, p. 333-346, mars 2014, doi: 10.1080/09603107.2013.877568. 